\title{
Studies on the Inhibition of Erythrocyte and Hepatic Delta-Aminolevulinic Acid Dehydratase Activities and its Restoration in Mice Exposed to Lead
}

\author{
Naomi KOGA, Yukio HIRAI, Tohru HASEgAWA \\ and Katsumaro TOMOKUNI \\ Department of Community Health Science, Saga Medical School, \\ Nabeshima, Saga 840-01, Japan
}

(Received February 13, 1984 and in revised form April 2, 1984)

\begin{abstract}
The comparative study on lead-induced inhibition of delta-aminolevulinic acid dehydratase (ALA-D) activity in both blood and liver and that on its restoration were performed using the mice which were given ad libitum a lead containing water (500 ppm as lead) for 30 days. The ALA-D inhibition in the liver was very mild compared with that in the blood, in spite of high accumulation of lead into the liver. The depressed ALA-D activity in both blood and liver was rapidly restored by means of the cessation of lead exposure.

The gel filtration chromatography showed that the chromatographic ellution pattern of zinc from the supernatant of the liver homogenate corresponds well to that of protein-like substances of the supernatant. However, the lead-binding protein in the liver was not detected in mice exposed to lead for 30 days.
\end{abstract}

Key words: Lead-exposed mice-Erythrocyte ALA-D-Liver ALA-D-Inhibition and restoration-Liver zinc-Gel filtration chromatography

\section{INTRODUCTION}

Delta-Aminolevulinic acid dehydratase (EC 4.2.1.24) (ALA-D) catalyzes the second reaction in the heme biosynthetic pathway in mammals, the condensation of two moles of delta-aminolevulinic acid (ALA) to produce one mol of porphobilinogen (PBG). This enzyme is largely contained in blood and liver.

Many investigators ${ }^{1-8)}$ have reported that the degree of inhibition of erythrocyte ALA-D activity has a close correlation with the concentration of lead in blood and that, therefore, its enzyme activity is very useful as indicators of lead exposure and lead poisoning.

On the other hand, the relationship between lead exposure and hepatic ALA-D activity appears to be seldom reported by reason that it has no application to evaluate the degree of lead exposure in the field of industrial health. But, inhibition of ALA-D in liver might inflict the some damage on the biosynthesis of heme being a part of cytochrome $\mathrm{P}-450$ which is necessary for many detoxification 
processes in the liver.

Previously, Tomokuni ${ }^{9)}$ has reported the difference of sensitivity between erythrocyte ALA-D and hepatic ALA-D in the lead-exposed mice. However, the data concerning the restoration from inhibited ALA-D activity by the cessation of lead exposure were not introduced in his paper.

In the present study, we mainly investigated the time-dependent response on the inhibition of ALA-D and its restoration, using the lead-exposed mice.

\section{Materials ANd Methods}

Lead exposure: DDY male mice weighing 30 to $40 \mathrm{~g}$ were used as an experimental animal. They were divided at random into 7 groups (5-6 mice per one group) and were fed a solid diet from the Oriental Yeast Company (Japan). One group was used as control and the other group was given ad libitum a lead containing water ( $500 \mathrm{ppm}$ as lead) for 30 days. The drinking water containing lead was prepared from lead acetate (reagent grade). At appropriate intervals during lead exposure and after the cessation of exposure, the mice were light anesthetized with ethyl ether and the blood was withdrawn into a glass test-tube through heparinized capillary tubes by an orbital bleeding technique. Then the liver was excised and rinsed in the ice-cold $0.15 \mathrm{M} \mathrm{NaCl}$ solution.

Determination of $A L A-D$ activity: The erythrocyte ALA-D activity was measured according to a slight modification of Nikkanen et al. ${ }^{10)}$ method. The enzyme solution was prepared by hemolyzing $0.2 \mathrm{ml}$ of heparinized whole blood with $1.3 \mathrm{ml}$ of distilled water. To this enzyme solution added $0.5 \mathrm{ml}$ of $0.2 \mathrm{M}$ sodium phosphate buffer $(\mathrm{pH} 6.7)$ and $0.5 \mathrm{ml}$ of $20 \mathrm{mM}$ ALA solution, and it was incubated for one $\mathrm{hr}$ at $37^{\circ} \mathrm{C}$. After stopping the reaction by adding $1 \mathrm{ml}$ of $10 \% \mathrm{TCA}$, it was centrifuged for $5 \mathrm{~min}$ at 3,000 rpm. One $\mathrm{ml}$ of the supernatant was mixed with $3 \mathrm{ml}$ of Ehrlich's reagent and the absorbance of the colored solution was measured at $555 \mathrm{~nm}$. The erythrocyte ALA-D activity was expressed as $\mu$ mole of PBG formed per hr per $l$ of erythrocyte (RBC).

The hepatic ALA-D activity was measured according to the following procedure: The fresh liver was homogenized with 20 volumes of the ice-cold $0.15 \mathrm{M} \mathrm{NaCl}$ solution using a Potter-Elvehjem homogenizer and the homogenate was centrifuged at $3,000 \mathrm{rpm}$ for $5 \mathrm{~min}$. $1.5 \mathrm{ml}$ of the supernatant was used as the enzyme solution. The condition cf hepatic ALA-D assay was the same as that of erythrocyte ALA-D. The hepatic ALA-D activity was expressed as $\mu$ mole of PBG formed per hr per g tissue (wet weight).

Gel filtration chromatography: The liver was homogenized with 3 volumes of $25 \mathrm{mM}$ sodium phosphate buffer ( $\mathrm{pH} \mathrm{7.0)}$ and the homogenate was centrifuged at $40,000 \mathrm{~g}$ for $30 \mathrm{~min}$. The supernatant (about $1 \mathrm{ml}$ ) was gel-filtrated thrcugh 
a Sephadex G-75 column $(1.6 \times 64 \mathrm{~cm})$ which was equilibrated with $25 \mathrm{mM}$

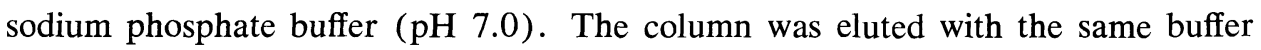
at a flow rate of $15-20 \mathrm{ml} / \mathrm{hr}$ and the fractions of $4.0 \mathrm{ml}$ volume were collected. This procedure was carried out at room temperature. The measurement of absorbance at both 280 and $254 \mathrm{~nm}$ and the determination of lead and zinc were performed for each fraction.

Determination of some metals: The determination of lead, zinc and copper in the biological materials was performed by flameless atomic absorpiton spectrophotometry using a Shimadzu Model AA-646 atomic absorption spectrophotometer equipped with a deuterium background corrector and a graphite furnace atomizer (GFA-3). A sample for the blood lead analysis was prepared by hemolyzing $0.1 \mathrm{~m} l$ of whole blood with $0.4 \mathrm{ml}$ of distilled water. The sample for the liver metal analyses was prepared as follows: The liver $(0.8-1.2 \mathrm{~g})$ was digested in $150 \mathrm{~m} l \mathrm{Kjeldahl}$ flask containing $25 \mathrm{~m} l$ of a nitric : perchloric acid (5:1) mixture. The cooled residue was appropriately diluted with distilled water and this solution was used as sample.

Other analyses: Hemoglobin $(\mathrm{Hb})$ was determined by the standard method after conversion to cyanmethemoglobin. Hematocrit $(\mathrm{Ht})$ levels were measured by the use of a microcapillary centrifuge.

\section{Results}

Table 1 summarizes the data concerning $\mathrm{Hb}, \mathrm{Ht}$ and ALA-D activity in the

Table 1. Levels of hemoglobin, hematocrit, and erythrocyte and hepatic ALA-D activities in the mice exposed to lead

\begin{tabular}{|c|c|c|c|c|c|c|}
\hline \multirow{2}{*}{ Group } & \multirow{2}{*}{$\begin{array}{l}\text { Hemoglobin } \\
\text { g/100 ml }\end{array}$} & \multirow{2}{*}{$\underset{\%}{\text { Hematocrit }}$} & \multicolumn{2}{|c|}{$\begin{array}{l}\text { Erythrocyte ALA-D } \\
\text { activity }\end{array}$} & \multicolumn{2}{|c|}{$\begin{array}{l}\text { Hepatic ALA-D } \\
\text { activity }\end{array}$} \\
\hline & & & $\mu \underset{\mathrm{RBC}}{\mathrm{PBG}} / \mathrm{hr} / l$ & $(\%)$ & $\underset{\text { tissue }}{\mu \mathrm{mol}} \mathrm{PBG} / \mathrm{hr} / \mathrm{g}$ & $(\%)$ \\
\hline Control & $14.5 \pm 0.4$ & $46 \pm 1.4$ & $494 \pm 102$ & $(100)$ & $1.71 \pm 0.23$ & $(100)$ \\
\hline \multicolumn{7}{|c|}{ Days on exposure } \\
\hline 7 & $15.2 \pm 0.6$ & $46 \pm 1.9$ & $57 \pm 41^{* * *}$ & $(12)$ & $1.05 \pm 0.28^{* *}$ & ( 61$)$ \\
\hline 14 & $15.2 \pm 0.3$ & $47 \pm 2.2$ & $57 \pm 19 * * *$ & $(12)$ & $1.42 \pm 0.24$ & $(83)$ \\
\hline 30 & $14.7 \pm 1.3$ & $47 \pm 2.5$ & $68 \pm 17 * * *$ & $(14)$ & $1.10 \pm 0.22 * *$ & ( 64) \\
\hline \multicolumn{7}{|c|}{$\begin{array}{l}\text { Days after the } \\
\text { exposure cessation }\end{array}$} \\
\hline 7 & $13.4 \pm 0.5^{* *}$ & $46 \pm 0.9$ & $288 \pm 31^{* *}$ & $(58)$ & $1.70 \pm 0.17$ & ( 99$)$ \\
\hline 14 & $14.8 \pm 0.8$ & $45 \pm 2.7$ & $426 \pm 99$ & $(86)$ & $1.56 \pm 0.34$ & ( 91$)$ \\
\hline 28 & $14.2 \pm 0.7$ & $44 \pm 1.8$ & $544 \pm 74$ & $(110)$ & $2.08 \pm 0.14^{*}$ & (122) \\
\hline
\end{tabular}

Each group consists of $5 \sim 6$ mice.

Each value is the mean \pm standard deviation (S.D.).

Significantly different from the control; * $\mathbf{P}<0.05$, ** $\mathbf{P}<0.01, * * * \mathbf{P}<0.001$. 
Table 2. In vitro effect of lead on normal ALA-D activity in the blood and liver when lead acetate was added to the reaction medium at the concentration of $10^{-6}$ to $10^{-4} \mathrm{M}$

\begin{tabular}{ccc}
$\begin{array}{c}\text { Concentration of lead } \\
(\mathrm{M})\end{array}$ & $\begin{array}{c}\text { Erythrocyte } \\
(\%)\end{array}$ & $\begin{array}{c}\text { Hepatic ALA-D activity } \\
(\%)\end{array}$ \\
\hline 0 & 100 & 100 \\
$10^{-6}$ & 73 & 64 \\
$10^{-5}$ & 28 & 14 \\
$10^{-4}$ & 8 & 11 \\
\hline
\end{tabular}

Each value represents the mean obtained by duplicate analyses.

control and lead-exposed mice. The significant change in both $\mathrm{Hb}$ and $\mathrm{Ht}$ levels were not observed during the experimental term, except that only $\mathrm{Hb}$ level was significantly decreased $(P<0.01)$ on the 7 th day after the cessation of lead exposure. The cause of this depression is unknown. Erythrocyte ALA-D activity was rapidly decreased by lead exposure and its level was inhibited until $12 \%$ of the control on the 7th day of the exposure. Further depression of ALA-D activity was not observed during exposure. On the other hand, the inhibited erythrocyte ALA-D activity was rapidly restored with the cessation of lead exposure, and the activity was detected to recover completely between the 14th day and the 28 th day after the exposure cessation.

Hepatic ALA-D activity was moderately depressed by lead exposure. This activity on the 7 th day of lead exposure was $61 \%$ of the control and this level was almost equal to that on day 30 of the exposure. Hepatic ALA-D also recovered rapidly from the inhibition by the cessation of lead exposure.

Table 2 shows the comparison of in vitro effects of lead on the normal erythrocyte

Table 3. Blood lead level and the concentrations of lead, zinc and copper in the liver, obtained from control and lead-exposed mice

\begin{tabular}{|c|c|c|c|c|}
\hline \multirow{2}{*}{ Group } & \multirow{2}{*}{$\frac{\text { Blood }}{\text { Lead }(\mu \mathrm{g} / 100 \mathrm{~m} l)}$} & \multicolumn{3}{|c|}{ Liver } \\
\hline & & Lead $(\mu \mathrm{g} / \mathrm{g})$ & $\operatorname{Zinc}(\mu \mathrm{g} / \mathbf{g})$ & Copper $(\mu \mathrm{g} / \mathrm{g})$ \\
\hline Control & $4 \pm 2$ & $0.06 \pm 0.05$ & $65.6 \pm 14.3$ & $10.3 \pm 2.0$ \\
\hline \multicolumn{5}{|c|}{ Days on exposure } \\
\hline 7 & $36 \pm 10^{* * *}$ & $1.62 \pm 0.68^{* * *}$ & $67.6 \pm 6.2$ & $8.9 \pm 1.8$ \\
\hline 14 & $30 \pm 14^{* *}$ & $1.05 \pm 0.24^{* * *}$ & $67.2 \pm 14.8$ & $10.8 \pm 2.0$ \\
\hline 30 & $45 \pm 20^{* * *}$ & $2.00 \pm 0.95 * * *$ & $83.7 \pm 24.9$ & $11.8 \pm 5.1$ \\
\hline \multicolumn{5}{|c|}{$\begin{array}{l}\text { Days after the } \\
\text { exposure cessation }\end{array}$} \\
\hline 7 & $6 \pm 1$ & $0.53 \pm 0.15^{* * *}$ & $59.1 \pm 10.4$ & $9.2 \pm 6.6$ \\
\hline 14 & $4 \pm 1$ & $0.27 \pm 0.14^{* *}$ & $51.6 \pm 4.8$ & $9.7 \pm 6.6$ \\
\hline 28 & $8 \pm 1^{*}$ & $0.10 \pm 0.04$ & $57.5 \pm 12.9$ & $9.2 \pm 3.1$ \\
\hline
\end{tabular}

Each group consists of $5 \sim 6$ mice.

Each value is the mean \pm standard deviation (S.D.).

Significantly different from the control; * $\mathrm{P}<0.05$, ** $\mathrm{P}<0.01$, *** $\mathrm{P}<0.001$. 
and hepatic ALA-D activities when lead acetate was added to the reaction medium at an appropriate concentration. The in vitro inhibition of hepatic ALA-D activity by lead was almost similar to that of erythrccyte ALA-D activity, in contrast to the results obtained from in vivo experiment.

Table 3 summarizes the results concerning the concentration of some metals in blood and liver. The concentration of lead in blood was rapidly increased with a lapse of exposure time and its level became 9-fold of the control on day 7 of the exposure. But, the increasing rate of blood lead between day 7 and day 30 of the exposure was very slow. On the other hand, the diminution of

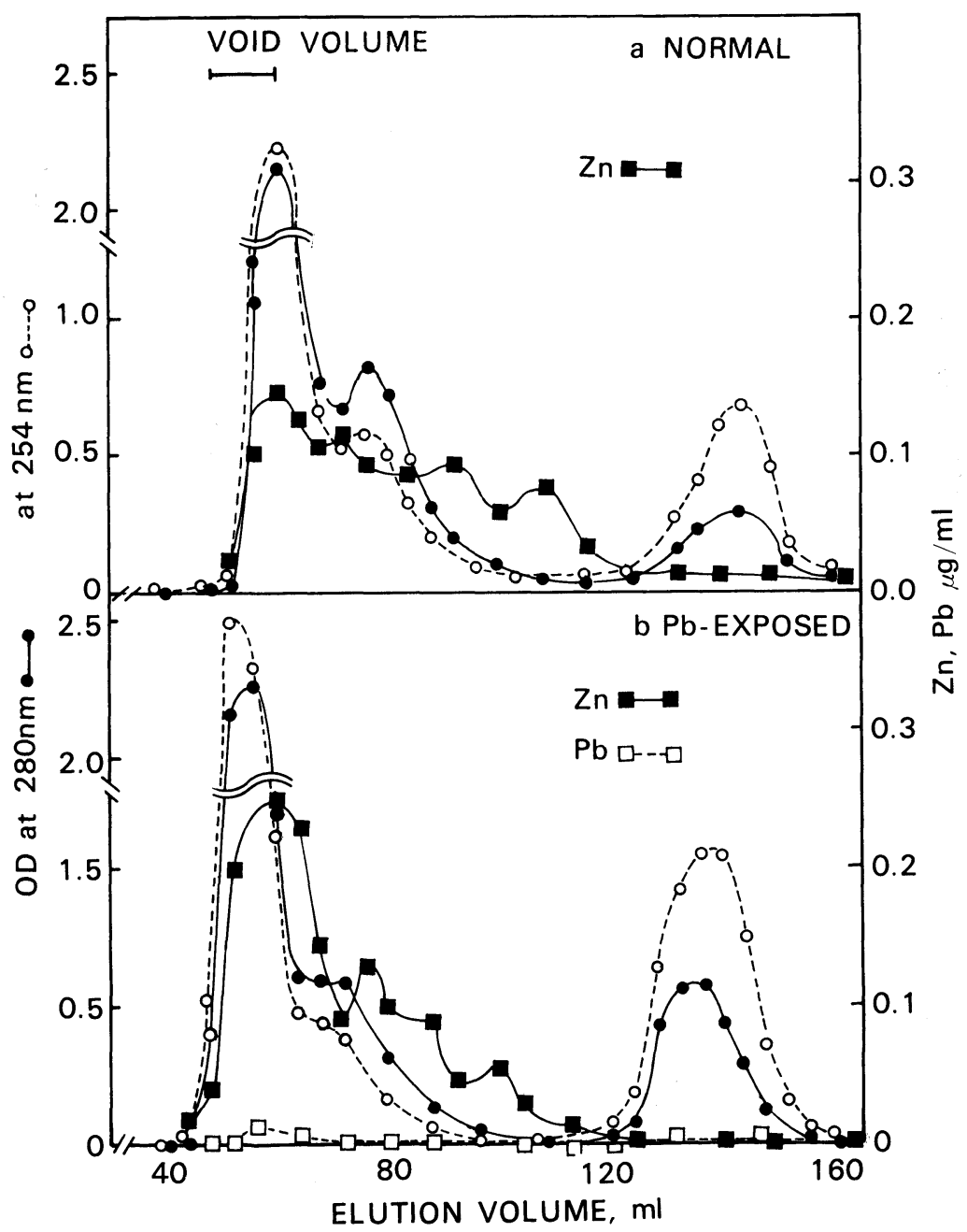

Fig. 1. Gel filtration chromatography on Sephadex G-75 for the $40,000 \mathrm{~g}$ supernatant of liver homogenate from normal mice (a) and the mice exposed to lead for 30 days (b). 
lead from blood after the exposure cessation was very rapid, and the blood lead concentraiton was decreased to almost the control level on day 7 after the cessation of exposure.

The accumulation of lead in the liver was much higher. The concentration of lead in the liver was increased up to 27 -fold of the control on day 7 of the exposure and up to 33-fold on day 30. The elimination of lead from the liver after the exposure cessation was very slow as compared with that from the blood.

The significant variation of the concentration of zinc and copper in liver were not detected among the control and treated groups.

The gel filtrations for $40,000 \mathrm{~g}$ supernatant of liver homogenate on Sephadex G-75 are shown in Fig. 1. Elution patterns at 280 and $254 \mathrm{~nm}$ were estimated to be no difference between normal and lead-exposed mice. The elution profile of zinc was also similar, suggesting that the distribution pattern of zinc corresponds roughly with that of substances detected at $280 \mathrm{~nm}$. The lead containing fraction could not be separated from the liver homogenate of the mice exposed to lead for 30 days.

\section{Discussion}

The finding that the ALA-D inhibition is greater in the blood than in the liver when animals were exposed to lead has been reported by several investigators. ${ }^{9,11,12)}$ However, the results concerning the restoration from the ALA-D inhibition in both blood and liver by the cessation of lead exposure were not indicated in their papers.

The aims of this work were to demonstrate the finding on the restoration of inhibited ALA-D activity by lead after cessation of lead exposure and that on the causative mechanism of different response between erythrocyte and hepatic ALA-D in lead-exposed mice.

It was indicated that the inhibited ALA-D activity in both blood and liver is rapidly restored by the cessation of lead exposure. It was also indicated that the ALA-D inhibition in the liver is very mild as compared with that in the blood, in spite of high accumulation of lead into the liver. This difference appears to be not due to the sensitivity of ALA-D itself for lead, judging from the result obtained by in vitro experiment using normal ALA-D enzyme (Table 2).

It has been reported that the lead-binding protein which is not present in normal erythrocytes was identified in the erythrocytes from individuals with industrial exposure to lead and this protein was closely related with an appearance of lead-induced toxicity, suggesting that it has the function of detoxifying the erythrocyte lead. ${ }^{13,14)}$ On the contrary, there are no reports on finding of lead-binding protein in the liver. In this context, zinc is well known to have an antagonistic effect on lead inhibition of ALA-D in vivo and in vitro. ${ }^{15-20)}$ Therefore, we noted the identification of lead-binding protein as well as the variation of zinc 
concentration in the liver of mice exposed to lead. But, we could not identify the lead-binding protein in the liver of mice exposed to lead for 30 days (Fig. 1).

The significant variation of zinc concentration in the liver was not detected, in addition, though it tended to increasing with the duration of lead exposure. Therefore, in the present study, we could not explain the causative mechanism of different response between erythrocyte ALA-D and hepatic ALA-D in the lead-exposed mice, by means of the findings on the lead-binding protein and zinc concentration in the liver.

Related studies are in progress.

\section{REFERENCES}

1) Hernberg, S., Nikkanen, J., Mellin, G. and Lillius, H. (1970). Delta-aminolevulinic acid dehydrase as a measure of lead exposure, Arch. Environ. Health, 21, 140.

2) Weissberg, J. B., Lipschutz, F. and Oski, F. A. (1971). Delta-aminolevulinic acid dehydratase activity in circulating blood cells. A sensitive laboratory test for the detection of childhood lead poisoning, New Engl. J. Med., 284, 565.

3) Hernberg, S., Tola, S., Nikkanen, J. and Valkonen, S. (1972). Erythrocyte deltaaminolevulinic acid dehydratase in new lead exposure, Arch. Environ. Health, 25, 109.

4) Lauwerys, R. R., Buchet, J. P. and Roels, H. A. (1973). Comparative study of effect of inorganic lead and cadmium on blood delta-aminolevulinate dehydratase in man, Brit. J. Ind. Med., 30, 359.

5) Tola, S., Hernberg, S., Asp, S. and Nikkanen, J. (1973). Parameters indicative of absorption and biological effect in new lead exposure; a prospective study, Brit. J. Ind. Med., 30, 134.

6) Sakurai, H., Sugita, M. and Tsuchiya, K. (1974). Biological response and subjective symptoms in low level lead exposure, Arch. Environ. Health, 29, 157.

7) Tomokuni, K. (1974). Delta-aminolevulinic acid dehydratase test for lead exposure, Arch. Environ. Health, 29, 274.

8) Tomokuni, K. and Ogata, M. (1976). Relationship between lead concentration in blood and biological response for porphyrin metabolism in workers occupationally exposed to lead, Arch. Toxicol., 35, 239.

9) Tomokuni, K. (1976). Different response of erythrocyte and hepatic delta-aminolevulinic acid dehydratases in mice treated with lead, Ind. Health, 14, 1.

10) Nikkanen, J., Hernberg, S. and Tola, S. (1972). Modifications of delta-aminolevulinic acid dehydratase test and their significance for assessing different intensities of lead exposure, Work Environ. Health, 9, 46.

11) Hammond, P. B. (1973). The relationship between inhibition of delta-aminolevulinic acid dehydratase by lead and lead mobilization by ethylenediamine tetraacetate (EDTA), Toxicol. Appl. Pharmacol., 26, 466.

12) Dieter, M. P. and Finley, M. T. (1979). Delta-aminolevulinic acid dehydratase enzyme acivity in blood, brain, and liver of lead-dosed ducks, Environ. Res., 19, 127.

13) Raghavan, S. R. V. and Gonick, H. C. (1977). Isolation of low-molecular-weight lead-binding protein from human erythrocytes, Proc. Soc. Exp. Biol. Med., 155, 164.

14) Raghavan, S. R. V., Culver, B. D. and Gonick, H. C. (1980). Erythrocyte lead-binding protein after occupational exposure. 1. Relationship to lead toxicity, Environ. Res., 22, 264.

15) Finelli, V. N., Klauder, D. S., Karaffa, M. A. and Petering, H. G. (1975). Interaction of zinc and lead on delta-amino-levulinate dehydratase, Biochem. Biophys. Res. Comm., 
$65,303$.

16) Border, E. A., Cantrell, A. C. and Kilroe-Smith, T. A. (1976). The in vitro effect of zinc on the inhibition of human delta-aminolevulinic acid dehydratase by lead, Brit. $J$. Ind. Med., 33, 85.

17) Haeger-Aronsen, B., Schütz, A. and Abdulla, M. (1976). Antagonistic effect in vivo of zinc on inhibition of delta-aminolevulinic acid dehydratase by lead, Arch. Environ. Health, 31, 215.

18) Thomasino, J. A., Zuroweste, E., Brooks, S. M., Petering, H. G., Lerner, S. I. and Finelli, V. N. (1977). Lead, zinc, and erythrocyte delta-aminolevulinic acid dehydratase: Relationship in lead toxicity, Arch. Environ. Health, 32, 244.

19) Tomokuni, K. (1979). Interaction of zinc and other metal on the activity of erythrocyte delta-aminolevulinic acid dehydratase in vitro, J. Toxicol. Sci., 4, 11.

20) Sakai, T., Yanagihara, S., Kunugi, Y. and Ushio, K. (1983). Mechanisms of ALA-D inhibition by lead and of its restoration by zinc and dithiothreitol, Brit. J. Ind. Med., 40, 61. 